\title{
ARTs in wild felid conservation programmes in Poland and in the world
}

\author{
Joanna Kochan ${ }^{1}$, Wojciech Niżański ${ }^{2}$, Nei Moreira ${ }^{3}$, \\ Zalmir Silvino Cubas ${ }^{4}$, Agnieszka Nowak ${ }^{1}$, Sylwia Prochowska ${ }^{2}$, \\ Agnieszka Partyka ${ }^{2}$, Wiesława Młodawska ${ }^{1}$, Józef Skotnicki ${ }^{5}$ \\ ${ }^{1}$ Institute of Veterinary Science, University of Agriculture in Kraków, 30-059 Kraków, Poland \\ ${ }^{2}$ Department of Reproduction and Clinic of Farm Animals, \\ Wrocław University of Environmental and Life Sciences, 50-366 Wrocław, Poland \\ ${ }^{3}$ Federal University of Paraná, Palotina, PR 85950-000, Brazil \\ ${ }^{4}$ ITAIPU Binacional, Refúgio Biológico Bela Vista, Foz do Iguaçu, PR 85856-970, Brazil \\ ${ }^{5}$ City Zoological Park and Garden in Kraków Charitable Foundation, 30-232 Kraków, Poland \\ wojtek.nizanski@gmail.com
}

Received: January 11, 2019 Accepted: July 2, 2019

\begin{abstract}
With the exception of the domestic cat, all felid species (Felidae) are currently threatened with extinction in their natural habitat. To develop effective and optimal wild cat conservation programmes with assisted reproductive technology (ART) it is necessary to combine advances from different disciplines of science, starting from the biology of the species, through research into the population and habitat, assisted reproductive technologies, establishment of gene banks, developing bioinformatic systems, and ending with biodiversity and endangered species management. In the last few years knowledge of felid reproduction has expanded considerably thanks to comparative studies utilising the domestic cat as a research model for endangered wild cats. Basic reproductive techniques utilised in both domestic cat breeding and rescuing wild felid populations that are threatened with extinction include semen collection and cryopreservation, artificial insemination, oocyte collection, in vitro maturation, in vitro fertilisation, somatic cloning, and embryo transfer. The main directions in which assisted reproductive technologies are being developed in wild cat conservation implementations and the contribution of Polish research centres in advancing these methods are presented.
\end{abstract}

Keywords: wild felids, assisted reproduction technology, conservation, biodiversity.

\section{Introduction}

With the exception of the domestic cat, all felid species (Felidae) are currently threatened with extinction in their natural habitat. It is mainly caused by the progress of civilisation leading to increased exploitation of natural resources, decreasing food sources for carnivores, poaching, and road accidents. The decline of populations and their fragmentation into small, isolated groups significantly hinder gene flow and thus pose a serious threat to the biodiversity of all cat species. Lynx and European wildcat populations in Poland are faced with these challenges. The Eurasian lynx (Lynx lynx) occurs in Poland in two isolated regions: the south-eastern part of the country is home to the Carpathian population, while the north-eastern areas are to the lowland population, which constitutes part of a dispersed Baltic population. Currently approximately 200 lynx inhabit Poland, with the most densely populated Carpathian Mountains providing a habitat for a population standing at about 100 individuals. The lowland population is divided into smaller, partly isolated groups with low chances of survival due to decreased biodiversity. Owing to the continuous decrease in the lowland population, the lynx was listed as an endangered species in Poland in 1995 $(43,44)$.

The situation of the European wildcat (Felis silvestris) is also very grave. The European wildcat is critically endangered in the entire territory of Poland 
and has been protected here since 1952. Its indigenous population is extremely small (approximately 100 individuals) and estimating its size is particularly difficult as wildcat tracks are often indistinguishable from the tracks left by domestic cats. European wildcat occurrence is limited to some sections of the Podkarpackie Province. The severely reduced population number and habitat fragmentation pose a threat to the proper genetic diversity of this species. This situation is further worsened by crossbreeding between the European wildcat and the domestic cat. In view of these factors, the situation of the Polish population of the European wildcat seems to be critical $(43,44)$.

The problems affecting our native populations of the lynx and the European wildcat affect all wild feline species. There is no doubt that implementation of advanced wild cat conservation programmes is essential. Wild felid conservation involves application of in situ methods, when a given species occurs in the natural habitat, or ex situ methods in centres with a conservation mandate (e.g. reserves or zoos) by taking advantage of the latest advances in biotechnology, cryobiology, and bioinformatics. Besides raising and breeding animals in captivity, ex situ methods include preservation of their genetic material, usually in cell banks.

Projects aimed at conservation of the indigenous population of the lynx and European wildcat utilising in situ methods have been implemented in Poland for many years. In the case of lynx conservation, these professional activities in particular cover restoration and improvement of the connection between large forests, improvement of the forest quality, improvement of the availability of food sources, and increasing biodiversity and expanding existing populations through reintroduction $(43,44)$. The areas inhabited by the European wildcat are usually protected as natural landscape parks or national parks (Bieszczady National Park and Magura National Park).

Despite a lot of efforts having been undertaken, the population of the lynx and European wildcat in Poland is not expanding into new or formerly inhabited areas and is failing to grow. The lynx and European wildcat conservation practices currently used do not guarantee population persistence. A similar situation applies to all wild cat species living in their natural habitat all over the world.

To develop effective and optimal wild cat conservation programmes it is necessary to combine advances from different disciplines of science, starting from the biology of the species, through research into the population and habitat, assisted reproductive technologies, establishment of gene banks, developing bioinformatic systems, and ending with biodiversity and endangered species management.

In the last few years knowledge of felid reproduction has expanded considerably thanks to comparative studies utilising the domestic cat as a research model for endangered wild cats. Basic reproductive techniques used both in domestic cat breeding and in rescuing wild felid populations that are threatened with extinction include semen collection and cryopreservation, artificial insemination (AI), oocyte collection, in vitro maturation (IVM), in vitro fertilisation (IVF), and embryo transfer (ET) (30, 31, $32,33,36,54,55)$. These biotechniques have been incorporated into wild cat conservation programmes all over the world, but in Poland their application is still uncustomary. A scientific and industrial consortium was established in 2015 to change that situation. It consists of Wrocław University of Environmental and Life Sciences, the University of Agriculture in Kraków, and the Zoological Garden in Kraków. Currently the consortium is involved in carrying out a project titled: "Increasing innovativeness and efficiency of the programmes for the conservation of the wild felid genetic resources through the establishment of a cell bank and practical implementation of the methods for in vitro embryo production" financed by the Polish National Centre for Research and Development. Consortium members have also initiated cooperation with the Federal University of Paraná in Brazil, whose researchers have extensive experience in implementing assisted reproductive techniques into wild felid conservation in South America $(23,24,25,26)$.

The main directions in which assisted reproductive technologies are being developed in wild cat conservation implementations and the contribution of Polish research centres in advancing these methods are presented in this article.

\section{Collecting semen from wild felids}

Until now electroejaculation has commonly been used as a technique for in vivo collection of semen from wild cats. Despite general anaesthesia this method causes severe muscle cramps and engenders considerable ethical controversy. Thus the application of this method has been partially limited in many countries. However, in countries where it is not banned, electroejaculation is used provided that all available safety measures have been taken and provided that the animal requires other treatments that require anaesthesia (Figs 1 and 2). Currently a method devised by Zambelli et al. (54) that involves urethral catheterisation after medetomidine administration is gaining greater popularity (Fig. 3). Medetomidine causes constriction of ejaculatory ducts and forces semen into the urethra, so that after placing a catheter into the urethra it is possible to draw a semen sample. In comparison with electroejaculation this method is far more humanitarian and safer for animals. Moreover, it can be used concurrently with other veterinary treatments. The research conducted by our team on the domestic cat so far indicates that this method is highly efficient and allows good quality semen to be obtained 
(37, 38). Moreover, it has been confirmed that semen obtained by means of urethral catheterisation and subsequently cryopreserved is capable of fertilisation (37). As far as wild felids are concerned, this procedure has already been applied for the Asiatic lion (Panthera leo persica) and the Asian golden cat (Catopuma temminckii) (19).

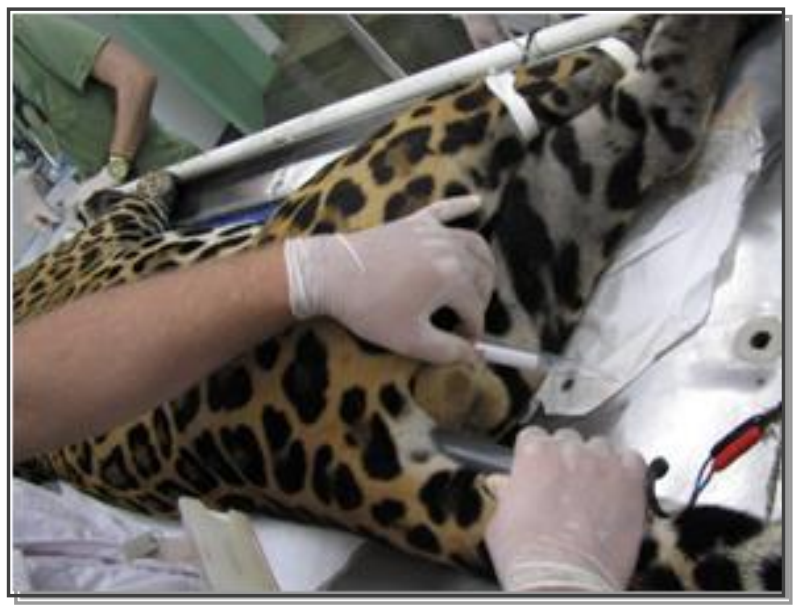

Fig. 1. Electroejaculation in a jaguar (Panthera onca)

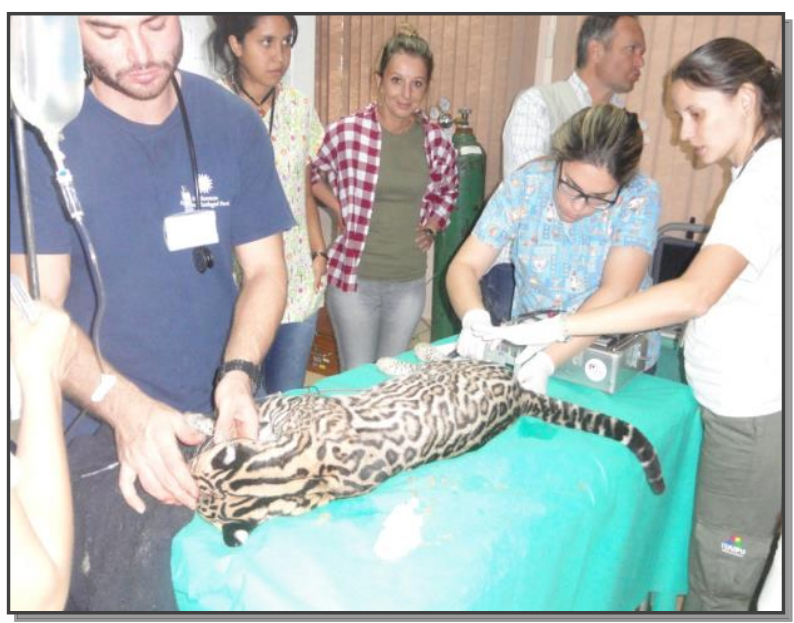

Fig. 2. Electroejaculation in an ocelot (Leopardus pardalis)

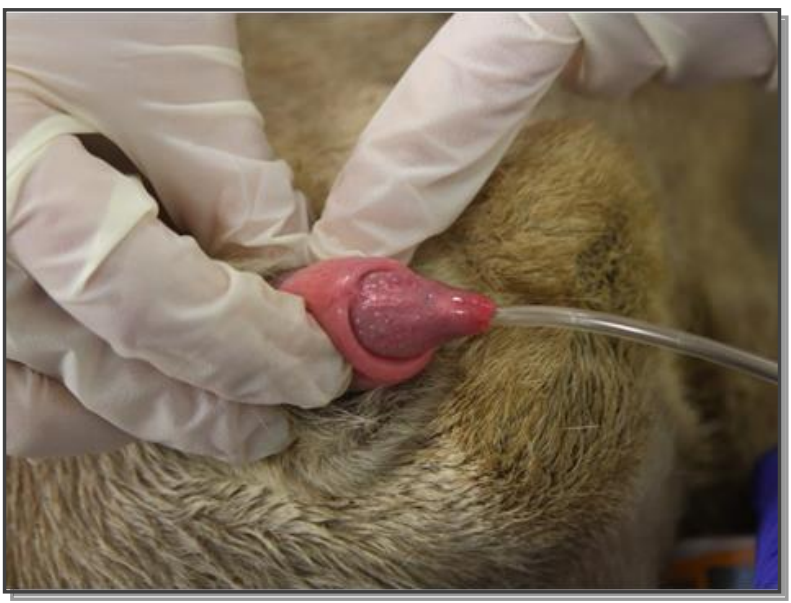

Fig. 3. Urethral catheterisation of a lion (Panthera leo)
In the case of the sudden death of a valuable individual it is possible to collect spermatozoa from the epididymis tail after previous testis isolation. Spermatozoa are obtained by multiple incisions of the epididymis tail suspended in a suitable medium, which leads to release of motile spermatozoa. This procedure allows live spermatozoa to be obtained even $24 \mathrm{~h}$ after animal death, provided that the testis was properly preserved, which is extremely important in the case of most precious endangered animals.

The sperm of most wild cat species and the domestic cat is characterised by a large number of morphological abnormalities, which has a negative impact on the reproductive potential of these animals $(30,40)$. It is believed that poor semen quality is associated with decreased heterozygosity owing to a small population size and limited gene flow between diverse populations (49).

\section{Obtaining oocytes from wild felids}

Oocytes are difficult to obtain and very valuable as their number is extremely low. Wild cat oocytes can be obtained in vivo or post mortem in emergency situations. In vivo oocyte collection involves laparoscopy under general anaesthesia preceded by hormonal stimulation. This procedure requires very expensive equipment and qualified research staff. Additionally, it cannot be performed without in-depth knowledge of the biology of reproduction, especially the oestrous cycle of a given species. This method obtains approximately 10 oocytes from one female individual $(12,16,17)$. Oocytes can also be collected post mortem in urgent situations. Unfortunately these cases usually concern old or sick individuals. Ovaries obtained post mortem can be stored at $5^{\circ} \mathrm{C}$ for $24 \mathrm{~h}$ without affecting oocyte developmental competence (Figs 5 and 6). It grants time for transporting ovaries after female death to a specialised laboratory (16). Oocytes from dead individuals can be recovered by means of follicular aspiration from isolated ovaries or by scarification of the ovarian cortex, depending on the ovary size. The number of oocytes collected from wild cats post mortem ranges between 0 and 102 and depends on multiple factors such as species, age, stage of the oestrus cycle, and health (16). It is common knowledge that with age the number of obtained oocytes is lower and they are characterised by poorer quality and reduced or almost utterly lost developmental competence (28). In some wild cat species, such as the lion (Panthera leo), puma (Felis concolor), and jaguar (Panthera onca), no oocytes were obtained from individuals older than 14 years (16), which is connected with gradual suppression of reproductive functions (28). When it comes to females at the same age representing other species, e.g. the tiger (Panthera tigris), leopard (Panthera pardus), and cheetah (Acinonyx jubatus), oocytes were successfully 
obtained, but a necessary condition for success was that animals were in good health. However, the number of oocytes was lower than in younger females and it amounted to 53 oocytes, while for very young and healthy females this number reached almost 100 (16).

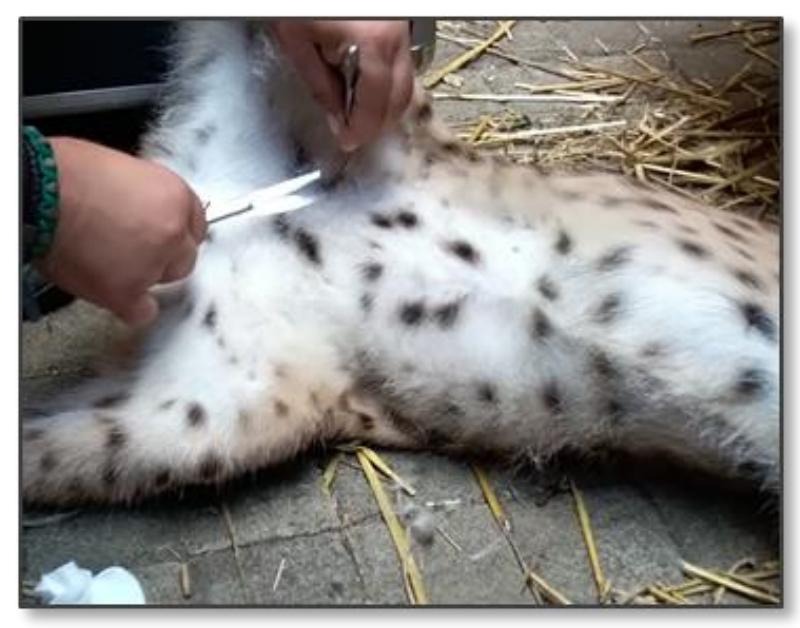

Fig. 4. Collection of skin sample from a lynx (Lynx lynx)

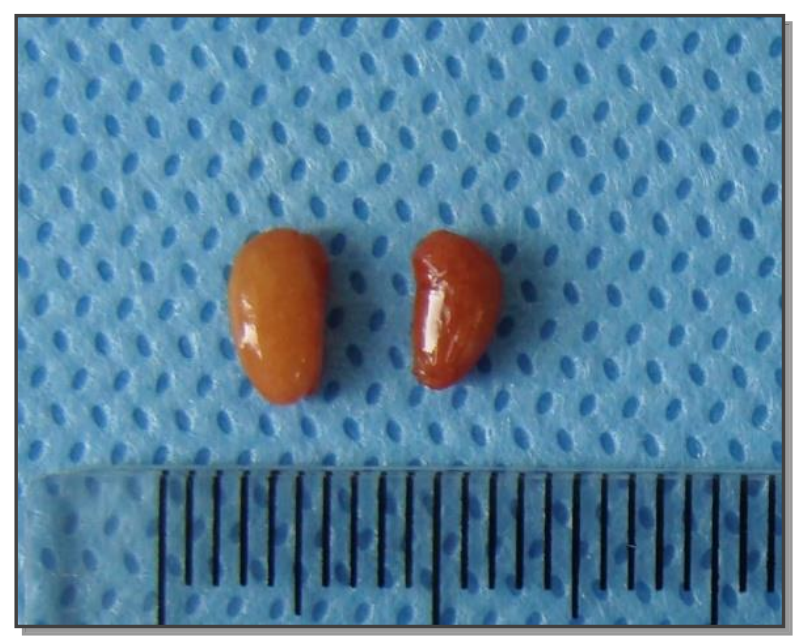

Fig. 5. Ovaries collected post mortem from a manul (Felis manul)

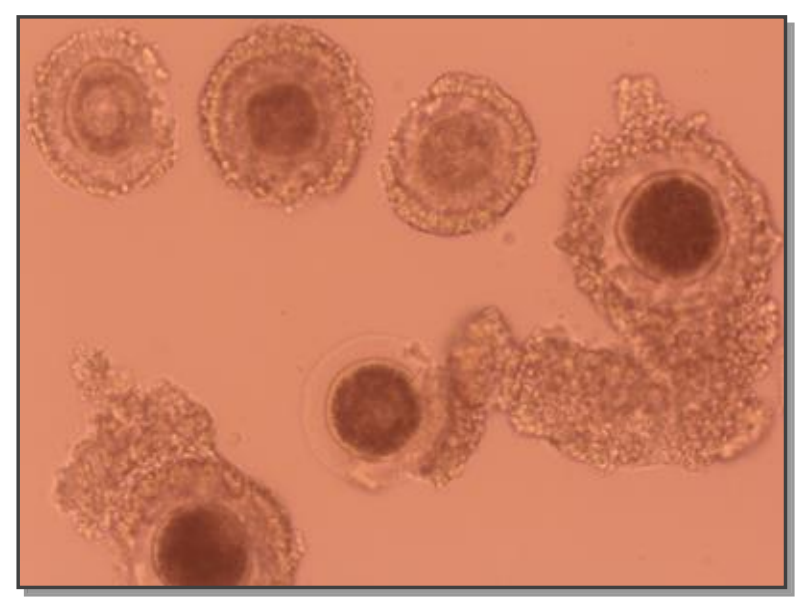

Fig. 6. Oocytes collected post mortem from a manul (Felis manul)
Experiments involving cat oocytes conducted so far have revealed the presence of two oocyte populations in domestic and wild cats: one with dark cytoplasm, cells of which are capable of being fertilised under in vitro conditions, and the other with pale cytoplasm, with limited fertilisation competence. The dark colour of the cytoplasm results from the presence of a large quantity of lipids. It must be remembered that after collecting oocytes only those with dark cytoplasm can be used in further in vitro procedures, that is $50 \%-80 \%$ of all harvested oocytes. What is more, oocytes recovered post mortem are immature and must be subjected to in vitro maturation (IVM). Only $50 \%-60 \%$ of domestic and wild cat oocytes undergo successful maturation, which significantly reduces the number of cells that can be utilised in consecutive in vitro procedures (16).

Due to a shortage of wild cat oocytes the majority of protocols for in vitro embryo production are tested on oocytes obtained from the domestic cat. The efficiency of wild cat semen cryopreservation was confirmed based on fertilisation trials conducted on specimens from the domestic cat $(7,8,46)$. Domestic cat oocytes can be used as recipients of nuclei in somatic cloning (10).

\section{Gamete and somatic cell banks}

Establishment of wild cat gamete and somatic cell banks allows the preservation of a vast genetic pool of endangered populations and provides a safeguard in case of failure to preserve a given species using in situ methods (14). In some populations the loss of merely one individual results in serious reduction of an already limited genepool, and preserving its genetic material prevents the loss of invaluable genes. Furthermore, gametes and somatic cells obtained from that individual can be used for many years after its death. With regard to assisted reproductive techniques and their application to wild species, the most serious difficulty is the technologist having at their disposal both female and male gametes in the same place and at the same time. Therefore cryopreservation of gametes and somatic cells and establishment of cell banks open up the possibility for successful delayed in vitro fertilisation or cloning.

The techniques for cryopreservation of spermatozoa have been sufficiently refined. The Department of Reproduction of the Wrocław University of Environmental and Life Sciences has significantly contributed to the development of these procedures. In the last few years the Department optimised methods for cryopreservation of semen obtained from the domestic cat and managed to freeze and bank semen from two wild felids: the ocelot (Leopardus pardalis) and lion (Panthera leo) (37, 38, 39). 
As far as efficiency of oocyte cryopreservation is concerned, it is subject to ongoing research. After applying traditional methods that are also used for other species, not more than $25 \%$ of feline oocytes retain their developmental competency after in vitro fertilisation $(3,21,22,32)$. An attempt was made at using vitrification as applied in human medicine, but the percentage of dividing feline embryos did not exceed $20 \%$ (5). Therefore, it is necessary to improve the efficiency of cryopreservation, especially in the case of oocytes obtained from valuable feline species.

Many centres store either oocytes or semen from various feline species in their gene banks. It would be highly useful and practical to create databases to enable further development of the procedures for in vitro fertilisation and provide research institutes with a possibility of exchanging their genetic resources to avoid cross-fertilisation using gametes from the domestic cat, which the shortage in spermatozoa or oocytes from wild felids might otherwise impose.

Besides wild cat gamete preservation, it is also necessary to secure and bank somatic cells, specifically fibroblasts harvested from skin sections. Obtaining small skin sections some millimetres long is not very invasive and the specimen can be taken as other veterinary treatments are administered (Fig. 4). The first bank of wild cat fibroblasts in Poland was established as part of the consortium's operations and pursuit of the project previously referred to. The bank resources are continually being expanded and currently it is in the possession of frozen cell lines from 14 wild cat species (the tiger, lion, snow panther, leopard, lynx, European wildcat, serval, caracal, ocelot, jaguarundi, manul, jungle cat, Geoffroy's cat, and sand cat) and 10 domestic cat breeds. Fibroblasts obtained from wild felids kept in the cell bank constitute a source of nucleus donors used in the procedures for cloning selected cat species or in cross-species cloning. Moreover, these cells can be utilised to conduct other research without the need to collect material from live animals. Thanks to the establishment of wild cat gene banks and provision of opportunities for exchanging genetic resources, Poland may become an attractive partner for other research centres and contribute to preserving the biodiversity of wild cats all over the world.

\section{In vitro fertilisation}

In vitro fertilisation (IVF) techniques allow offspring to be obtained from individuals with reduced fertility, from isolated populations, and even many years after the death of the animal using gametes stored in cell banks. The first domestic cat conceived utilising the classic IVF technique was born in 1988 (12). Since that time, IVF has been employed multiple times in wild cat reproduction, which has resulted in live births in the following wild feline species: the tiger, caracal, serval, fishing cat, Asiatic wildcat, and black-footed cat (4, 31, 32, 34, 36). It must be remembered that the efficiency of classic IVF depends mainly on good semen quality, which in the case of wild cats is extremely rare. With regard to using gametes subjected to cryopreservation, premature exocytosis of the cortical granules leads to zona pellucida hardening, which reduces the efficiency of classic IVF. Due to damage to the zona pellucida, classic IVF is commonly accompanied by polyspermy (20). These impediments can be eliminated by using another technique intracytoplasmic sperm injection (ICSI). In the case of sperm microinjection, fertilisation success or failure does not depend on specific changes having or not having taken place in gamete structure and function provided that sufficiently good DNA integrity has been maintained. The usefulness of ICSI in practical application to wild felids was confirmed in 1998 by Pope et al. (35), who were the first to achieve a live birth using this method. Since that time multiple further research papers in this discipline have been published $(1,2,32,35,37,40,42)$. Sperm microinjection has a lot of advantages but is a very complex and expensive technique that requires costly equipment and can only be performed by highly-qualified staff.

Both IVF methods on average result in a $50 \%$ rate for cell division and a $20 \%$ rate in achieving the blastocyst stage $(6,9,47)$. A Polish research team has been successfully producing domestic cat embryos under in vitro conditions for many years and the results are comparable to those obtained by other international centres (Figs 7 and 8).

\section{Somatic cloning}

Cloning is a technique that has generated abundant expectations among researchers all over the world. Cloning Dolly the sheep has created new prospects and opportunities for the practical application of somatic cloning (50), as it is the only method that yields a large number of individuals with valuable features and precisely specified genotypes. Further development of cloning techniques holds great potential for preserving many endangered animals. The first clone of the domestic cat was produced in 2002 in Texas, USA (45). Since that time many cloned kittens have been brought into the world as a result of scientific research or commercial cloning of selected individuals from different domestic cat breeds $(51,52,53)$.

After successful domestic cat cloning researchers became aware that application of this method created an opportunity to save the gene pool of wild felids that are on the verge of extinction. From the ensuing work, the first wild cat - the African wildcat - was cloned in New Orleans in 2003 (9). Seven kittens resulted, which produced offspring in 2005. The fact that cloning requires only a tiny skin section to establish fibroblast lines that provide the source of genetic material is an 
unquestionable advantage of this technique. When it comes to recipient cells for nuclei, there are two choices: either oocytes of the same species can be used, or if there is a shortage of such cells from valuable species, oocytes obtained from the domestic cat or other species can be applied (cross-species cloning) $(11,27)$.

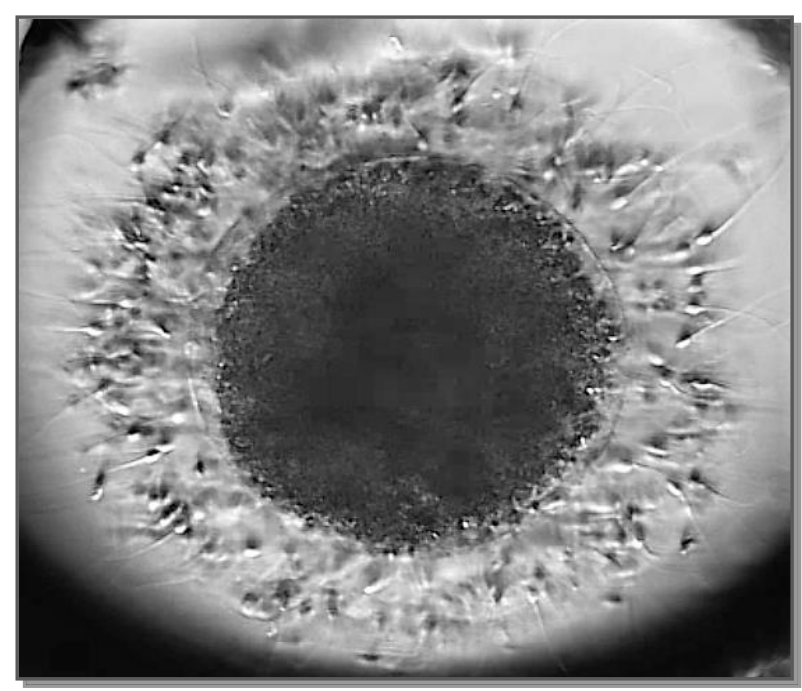

Fig. 7. In vitro fertilisation in domestic cat

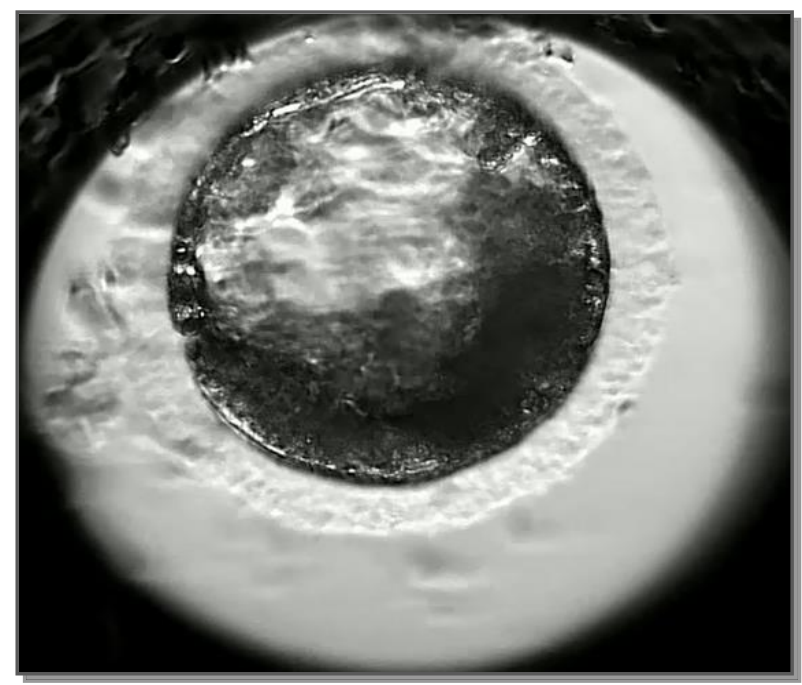

Fig. 8. Blastocyst after IVF in domestic cat

Somatic cloning allows the use of cells from adult individuals or foetuses, e.g. after stillbirth. It has been demonstrated that foetal fibroblasts are characterised by increased proliferation capacity and in that case cloning is more efficient than when cells from adult animals are used $(18,50)$. It has also been noticed that foetal fibroblasts display higher developmental potential. The establishment of a fibroblast bank by the consortium involved acquiring cells from adult individuals of different ages and from stillborn foetuses.

Cloning efficiency evaluated by the number of dividing embryos is higher than that of various IVF techniques $(70 \%$ vs. $50 \%)$. However, only $10 \%$ of embryos manage to reach the stage of a blastocyst (18, 48, 51).

\section{Embryo transfer}

Transfer of embryos to the recipient mother should be the final stage confirming the efficiency of IVF or cloning. As far as cats are concerned, embryos are usually transferred to recipient mothers from other species or subspecies (cross-species transfer). Many Asiatic wildcat, African wildcat, and black-footed cat kittens conceived as a result of IVF or cloning were carried by domestic cat mothers $(10,11,31,32,36)$. However, tiger, caracal, ocelot, and serval cubs, as larger wild cat species were born as a result of intraspecies transfer $(4,35)$.

Early embryos with few blastomeres can be transferred to the Fallopian tubes using classic surgery (12), while embryos at the blastocyst stage are transferred to the uterus with classic or laparoscopic surgery $(10,32,36)$. There is also a possibility to transfer embryos through the cervix using an endoscope, similarly to insemination (55), but this technique is still being investigated.

To increase the chances of pregnancy, several dozen embryos are usually transferred. It has been proved that transferring more than 12 embryos significantly increases the chances of pregnancy over the chances when transplanting a lower number (31). Evidence of this is the cloning the African wildcat, in which pregnancy was only achieved after transferring 30 embryos (9).

The success rate of embryo transfer varies extremely, from $0 \%$ to up to $100 \%(12,32)$. Pregnancy rates with cloned embryos are lower by $15 \%-30 \%$ than those with IVF embryos $(15,51)$.

Conflict of Interest Statement: The authors declare that there is no conflict of interests regarding the publication of this article.

Financial Disclosure Statement: Publication costs were met by the co-authors. The research was funded by the Polish National Centre for Research and Development (NCBiR), under grant NCBiR PBS3/B8/16/2015.

Animal Rights Statement: The experiments on animals were conducted in accordance with local Ethical Committee laws and regulations as regards care and use of laboratory animals. 


\section{References}

1. Bogliolo L., Leoni I.G., Ledda S., Naitana S., Zedda M., Carluccio A., Pau S.: Intracytoplasmic sperm injection of in vitro matured oocytes of domestic cats with frozen-thawed epididymal spermatozoa. Theriogenology 2001, 56, 955-967.

2. Buarpung S., Tharasanit T., Comizzoli P., Techakumphu M.: Feline spermatozoa from fresh and cryopreserved testicular tissues have comparable ability to fertilize matured oocytes and sustain the embryo development after intracytoplasmic sperm injection. Theriogenology 2013, 79, 149-158.

3. Cocchia N., Ciani F., Russo M., El Rass R., Rosapane I., Avallone L., Tortora G., Lorizio R.: Immature cat oocyte vitrification in open pulled straws (OPSs) using a cryoprotectant mixture. Cryobiology 2010, 60, 229-234.

4. Donoghue A.M., Johnston L.A., Seal U.S., Armstrong D.L., Tilson R.L., Wolf P., Petrini L.G., Simmons T., Groos T., Wildt D.E.: In vitro fertilization and embryo development in vitro and in vivo in the tiger (Panthera tigris). Biol Reprod 1990, 43, 733-744.

5. Fernandez-Gonzalez L., Jewgenow K.: Cryopreservation of feline oocytes by vitrification using commercial kits and slush nitrogen technique. Reprod Domest Anim 2017, 52, 230-234.

6. Freistedt P., Stojkovic M., Wolf E., March J., Il A.J.: Efficient in vitro production of cat embryos in modified synthetic oviduct fluid medium: effects of season and ovarian status effect of sperm treatment of cat embryos. Biol Reprod 2001, 65, 9-13.

7. Gañán N., González R., Garde J.J, Martínez F., Vargas A., Gomendio M., Roldan E.R.: Assessment of semen quality, sperm cryopreservation and heterologous IVF in the critically endangered Iberian lynx (Lynx pardinus). Reprod Fertil Dev $2009,2,848-859$.

8. Gañán N., González R., Sestelo A., Garde J.J., Sánchez I., Aguilar J.M., Gomendio M., Roldan E.R.: Male reproductive traits, semen cryopreservation, and heterologous in vitro fertilization in the bobcat (Lynx rufus). Theriogenology 2009, 72, $341-52$.

9. Gómez M.C., Pope C.E., Giraldo A., Lyons L.A., Harris R.F., King A.L., Cole A., Godke R.A., Dresser B.L.: Birth of African wildcat cloned kittens born from domestic cats. Clon Stem Cells 2004, 6, 247-258.

10. Gómez M.C., Pope C.E., Harris S.R., Mikota S., Dresser B.L.: Development of in vitro matured, in vitro fertilized domestic cat embryos following cryopreservation, culture and transfer. Theriogenology 2003, 60, 239-251.

11. Gómez M.C., Pope C.E., Kutner R.H., Ricks D.M., Lyons L.A., Ruhe M., Dumas C., Lyons J., López M., Dresser B.L., Reiser J.: Nuclear transfer of sand cat cells into enucleated domestic cat oocytes is affected by cryopreservation of donor cells. Clon Stem Cells 2008, 10, 469-483.

12. Goodrowe K.L., Wall R.J., O’Brien S.J., Schmidt P.M., Wildt D.E.: Developmental competence of domestic cat follicular oocytes after fertilization in vitro. Biol Reprod 1988, $39,355-372$

13. Howard J.G.: Semen collection and analysis in nondomestic carnivores. In: Zoo and Wild Animal Medicine, edited by M.E. Fowler, W.B. Saunders, Philadelphia, 1993, pp. 390-399.

14. Holt W.V.: Cryobiology, wildlife conservation and reality. Cryo Letters 2008, 29, 43-52.

15. Imsoonthornruksa S., Sangmalee A., Prirattana K., Parnpai R., Ketudat-Cairns M.: Development of intergeneric and intrageneric somatic cell nuclear transfer (SCNT) cat embryos and the determination of telomere length in cloned offspring. Cell Reprogram 2012, 14, 79-87.

16. Johnston L.A., Donoghue A.M., O'Brien S.J., Wildt D.E.: Rescue and maturation in vitro of follicular oocytes collected from nondomestic felid species. Biol Reprod 1991, 45, 898-906.

17. Johnston L.A., O'Brien S.J., Wildt D.E.: In vitro maturation and fertilization of domestic cat follicular oocytes. Gamete Res 1989, $24,343-356$.
18. Kitiyanat Y., Saikhun J., Pavasuthipaisit K.: Somatic cell nuclear transfer in domestic cat oocytes treated with IGF-I for in vitro maturation. Theriogenology 2003, 59, 1775-1786.

19. Lueders I., Ludwig C., Schroeder M., Mueller K., Zahmel J., Dehnhard M.: Successful nonsurgical artificial insemination and hormonal monitoring in an Asiatic golden cat (Catopuma temmincki). J Zoo Wildl Med 2014, 45, 372-379.

20. Luvoni G.C.: Gamete cryopreservation in the domestic cat. Theriogenology 2006, 66, 101-111.

21. Merlo B., Iacono E., Regazzini M., Zambelli D.: Cat blastocysts produced in vitro from oocytes vitrified using the cryoloop technique and cryopreserved electroejaculated semen. Theriogenology 2008, 70, 126-130.

22. Mikołajewska N., Müller K., Niżański W., Jewgenow K.: Vitrification of domestic cat oocytes-effect on viability and integrity of subcellular structures. Reprod Domest Anim 2012, 47, 295-299.

23. Moreira N.: Exame andrológico e criopreservação de sêmen em felídeos selvagens (Andrological evaluation and semen cryopreservation in wild felids). Rev Bras Reprod Anim 2017, $41,312-315$.

24. Moreira N.: Técnicas reprodutivas para a conservação de felídeos silvestres (Reproductive techniques for the conservation of wild felids). Rev Bras Reprod Anim 2017, 41, 116-120.

25. Moreira N., Brown J.L., Moraes W., Swanson W.F., MonteiroFilho E.L.A.: Effect of housing and environmental enrichment on adrenocortical activity, behavior and reproductive cyclicity in the female tigrina (Leopardus tigrinus) and margay (Leopardus wiedii). Zoo Biol 2007, 26, 441-460.

26. Moreira N., Monteiro-Filho E.L.A., Moraes W., Swanson W.F., Graham L.H., Pasquali O.L., Gomes M.L.F., Morais R.N., Wildt D.E., Brown J.L.: Reproductive steroid hormones and ovarian activity in felids of the Leopardus genus. Zoo Biol 2001, $20,103-116$

27. Moro L.N., Jarazo J., Buemo C., Hiriart M.I., Sestelo A., Salamone D.F.: Tiger, Bengal, and domestic cat embryos produced by homospecific and interspecific zona-free nuclear transfer. Reprod Domest Anim 2015, 50, 849-857.

28. Nowak R.M., Paradiso J.L.: Walker's Mammals of the World, John Hopkins University Press, Baltimore, 1983, pp. 1061-1094.

29. Paz R.C.R.: Wildlife cats reproductive biotechnology. In: Current Frontiers in Cryobiology, edited by I.I. Katkov, IntechOpen, London, 2012, pp. 369-388.

30. Pope C.E.: Embryo technology in conservation efforts for endangered felids. Theriogenology 2000, 53, 163-174.

31. Pope C.E., Gómez M.C., Cole A., Dumas C., Dresser B.L.: Oocyte recovery, in vitro fertilization and embryo transfer in the serval (Leptailurus serval). Reprod Fertil Develop 2006, 18, 223-224.

32. Pope C.E., Gómez M.C., Dresser B.L.: In vitro embryo production and embryo transfer in domestic and non-domestic cats. Theriogenology 2006, 66, 1518-1524.

33. Pope C.E., Gómez M.C., Kagawa N., Kuwayama M., Leibo S.P., Dresser B.L.: In vivo survival of domestic cat oocytes after vitrification, intracytoplasmic sperm injection, and embryo transfer. Theriogenology 2012, 77, 531-538.

34. Pope C.E., Johnson C.A., McRae M.A., Keller G.L., Dresser B.L.: In vitro and in vivo development of domestic cat oocytes following intracytoplasmic sperm injection or subzonal insemination. Theriogenology 1995, 43, 302.

35. Pope C.E., Johnson C.A., McRae M.A., Keller G.L., Dresser B.L.: Development of embryos produced by intracytoplasmic sperm injection of cat oocytes. Anim Reprod Sci 1998, 53, 221-236.

36. Pope C.E., Keller G.L., Dresser B.L.: In vitro fertilization in domestic and non-domestic cats including sequences of early nuclear events, development in vitro, cryopreservation and successful intra- and interspecies embryo transfer. J Reprod Fertil 1993, 47, 189-201. 
37. Prochowska S., Niżański W.: In vitro fertilizing potential of urethral and epididymal spermatozoa collected from domestic cats (Felis catus). Polish J Vet Sci 2017, 20, 19-24.

38. Prochowska S., Niżański W., Ochota M., Partyka A.: Characteristics of urethral and epididymal semen collected from domestic cats. A retrospective study of 214 cases. Theriogenology 2015, 84, 1565-1571.

39. Prochowska S., Niżański W., Partyka A.: Comparative analysis of in vitro characteristics of fresh and frozen-thawed urethral and epididymal spermatozoa from cats (Felis domesticus). Theriogenology 2016, 86, 2063-2072.

40. Prochowska S., Niżański W., Partyka A., Kochan J., Młodawska W., Nowak A, Skotnicki J., Grega T., Pałys M.: Influence of the type of semen and morphology of individual sperm cells on the results of ICSI in domestic cats. Theriogenology 2018, doi.org/10.1016/j.theriogenology.2018.10.031.

41. Pukazhenthi B.S., Neubauer K., Jewgenow K., Howard J., Wildt D.E.: The impact and potential etiology of teratospermia in the domestic cat and its wild relatives. Theriogenology 2006, 66, $112-121$.

42. Ringleb J., Waurich R., Wibbelt G., Streich W., Jewgenow K.: Prolonged storage of epididymal spermatozoa does not affect their capacity to fertilise in vitro matured domestic cat (Felis catus) oocytes when using ICSI. Reprod Fertil Dev 2011, 23, $818-825$.

43. Schmidt K., Kowalczyk R., Ozolins J., Männil P., Fickel J.: Genetic structure of the Eurasian lynx population in northeastern Poland and the Baltic states. Conserv Genetics 2009, 10, 497-501.

44. Schmidt K., Ratkiewicz M., Konopiński M.K.: The importance of genetic variability and population differentiation in the Eurasian lynx (Lynx lynx) for conservation, in the context of habitat and climate change. Mammal Rev 2011, 41, 112-124.

45. Shin T., Kraemer D., Pryor J., Liu L., Rugila J., Howe L., Buck S., Murphy K., Lyons L., Westhusin M.: A cat cloned by nuclear transplantation. Nature 2002, 415, 859.

46. Swanson W.F., Maggs D.J., Clarke H.E., Newell A.E., Bond J.B., Bateman H.L., Kennedy-Stoskopf S.: Assessment of viral presence in semen and reproductive function of frozenthawed spermatozoa from Pallas' cats (Otocolobus manul) infected with feline herpesvirus. J Zoo Wildl Med 2006, 37 336-346.

47. Thongkittidilok C., Tharasanit T., Songasen N., Sananmuang T., Buarpung S., Techakumphu M.: Epidermal growth factor improves developmental competence and embryonic quality of singly cultured domestic cat embryos. J Reprod Dev 2015, 61, 269-276.

48. Wen D.C., Yang C.X., Cheng Y., Li J.S., Liu Z.H., Sun Q.Y., Zhang J.X., Lei L., Wu Y.Q., Kou Z.H., Chen D.Y.: Comparison of developmental capacity for intra- and interspecies cloned cat (Felis catus) embryos. Mol Reprod Dev 2003, 66, 38-45.

49. Wildt D.E., Bush M., Goodrowe K.L., Packer C., Pusey A.E., Brown J.L., Joslin P., O'Brien S.J.: Reproductive and genetic consequences of founding isolated lion populations. Nature 1987, 329, 328-331.

50. Wilmut I., Schnieke A.E., McWhir J., Kind A.J., Campbell K.H.: Viable offspring derived from fetal and adult mammalian cells. Nature 1997, 385, 810-813.

51. Yin X.J., Lee H.S., Lee Y.H., Seo Y.I., Jeon S.J., Choi E.G., Cho S.J., Cho S.G., Min W., Kang S.K., Hwang W.S., Kong I.K.: Cats cloned from fetal and adult somatic cells by nuclear transfer. Reproduction 2005, 129, 245-249.

52. Yin X.J., Lee H.S., Yu X.F., Choi E., Koo B.C., Kwon M.S., Lee Y.S., Cho S.J., Jin G.Z., Kim L.H., Shin H.D., Kim T., Kim N.H., Kong I.K.: Generation of cloned transgenic cats expressing red fluorescence protein. Biol Reprod 2008, 78, 425-431.

53. Yin X.J., Lee H.S., Yu X.F., Kim L.H., Shin H.D., Cho S.J., Choi E.G., Kong I.K.: Production of second-generation cloned cats by somatic cell nuclear transfer. Theriogenology 2008, 69, 1001-1006.

54. Zambelli D., Prati F., Cunto M., Iacono E., Merlo B.: Quality and in vitro fertilizing ability of cryopreserved cat spermatozoa obtained by urethral catheterization after medetomidine administration. Theriogenology 2008, 69, 485-490.

55. Zambelli D., Bini C., Kuster D.G., Molari V., Cunto M.: First deliveries after estrus induction using deslorelin and endoscopic transcervical insemination in the queen. Theriogenology 2015, $84,773-778$ 